\title{
超高強度繊維補強コンクリートを適用した 長大スパン・モノレール桁の技術開発
}

\author{
田中良弘 ${ }^{* 1}$ ・小林 隆*2 ・石堂正之*3 $・$ 大川真佐雄*4
}

\begin{abstract}
概 要 超高強度繊維補強コンクリート (Ductal) は, 高強度, 高じん性, 高流動, 高耐久性の特性を持つ材料であ り，この新素材を橋梁に適用すれば従来の PC 橋梁に比べ自重を 20 ～ $50 \%$ に低減することが可能となる。筆者らは，己 れまで実施した歩道橋や道路橋の施工実績から得られたD D ctal の設計・施工に関する蓄積技術を活用して，モノレール 軌道桁の技術開発を行い，桁長 $40 \mathrm{~m}$ のモノレール桁を完成した。開発した桁は，6 個のプレキャスト・セグメントが接

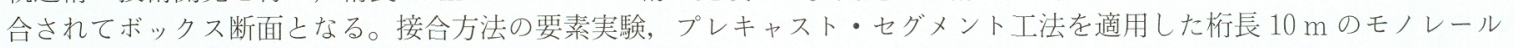
桁の施工性能実験，および載荷実験など，一連の実験・解析により施工・構造性能を検証した。

キーワード：超高強度繊維補強コンクリート, 跨座式モノレール桁, プレキャスト・セグメント, ウェットジョイント， ドライジョイント
\end{abstract}

\section{1.はじめに}

2002 年に日本初の超高強度繊維補強コンクリート (商品名：Ductal）を適用したスパン $50 \mathrm{~m}$ の「酒田タ らい橋」が山形県酒田市に完成した。2004 年には土木 学会から「超高強度繊維補強コンクリートの設計・施工 指針 (案) 」2) が発刊されて, この種の新素材による設計・ 施工に対する基盤が構築された。この 5 年間で Ductal を適用した歩道橋や道路橋, あるいは建築構造物の施工 実績は拡大の傾向にある。しかし, 鉄道橋への適用実績 はなかった。

東京モノレール株) と大成建設(柈は, 共同で Ductal を 適用した長大スパン・跨座式モノレール枌の技術開発を 実施してきた。東京モノレール羽田線の軌道桁は, 桁長 $20 \mathrm{~m}$ のプレストレス・コンクリート桁 (PC 桁) を標準 としている。モノレール軌道桁ではゴムタイヤ走行輪と 軌道桁上面之の摩擦を確保するためにコンクリート材料 を採用している。軌道桁の線形計画によっては道路横断 部などで長大スパンが必要とされる。これまでの PC 桁 では $20 \mathrm{~m}$ のスパンが限界とされてきたので, 東京モ， レール(株では主部材を鋼構造とし軌道走行面をコンクリー 卜構造とした長大スパンの合成軌道桁を採用してきた。 今回, 共同開発の結果, Ductal で製作されたプレキャ スト・セグメントを東京モノレールの昭和島車庫線にお いて接合して，桁長 $40 \mathrm{~m}$ のモノレール単線軌道桁を完 成することができた。

本報文は，プレキャスト・セグメント工法を長大スパン・

＊1 たなか・よしひろ/大成建設森 技術センター 栄誉研究員（正 会員)

*2こばやし・たかし/東京モノレール(侏) 取締役

*3 いしどう・まさゆき/東京モ/レール(粎) 取締役

*4 おおかわ・まさお 大成建設㑣) 東京支店 作業所長

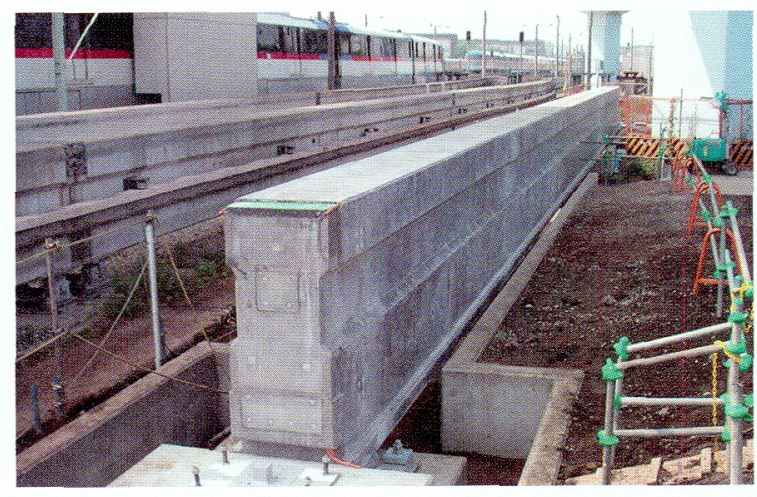

写真-1 桁長 $40 \mathrm{~m}$ モノレール桁の完成状況

モノレール桁に適用する際に鍵となる，接合要素実験， 桁長 $10 \mathrm{~m}$ のプロトタイプ軌道桁による施工性と構造安 全性の検証実験, また桁長 $40 \mathrm{~m}$ のモノレール桁（写真1 に完成写真）の施工に関して報告するものである。

\section{Ductal の材料特性}

Ductal は, 高強度, 高じん性, 高流動, 高耐久性の 特徵を有するコンクリート材料である。Ductal の一般

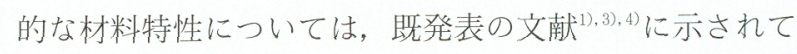
いるので, ここでは, 長大スパン・モノレール栴の技術 開発に関連する事項に絞って記述する。

Ductal を構造材として適用する際に従来のコンクリー 卜と大きく異なる点は, Ductal 自身が引張抵抗部材と して設計上, 考慮されることである。Ductal はセメン 卜, 珪砂, 珪石微粉末, 珪灰石微粉末, シリカフューム などの粉体に水と高性能減水材を配合して得られるマト リックスが材料特性の大部分を支配する。これらの粉体 の配合は，それぞれのセメント化学的役割之粒径分布か ら決められている。特に高強度で空隙のない緻密なマト リックスを作るために, 個々の原材料の配合設計には最 
表-1 Ductal と $40 \mathrm{~N} / \mathrm{mm}^{2}$ のコンクリートの材料比較

\begin{tabular}{|c|c|c|c|c|}
\hline 項 目 & 単 位 & Ductal $^{* 1}$ & $\begin{array}{l}40 \mathrm{~N} / \mathrm{mm}^{2} \text { の } \\
\text { コンクリート }\end{array}$ & 備 考 \\
\hline 水セメント比 & - & 0.22 & 0.4 & \\
\hline 压縮強度 & $\mathrm{N} / \mathrm{mm}^{2}$ & 180 & 40 & 設計特性值 \\
\hline ひび割れ発生強度 & $\mathrm{N} / \mathrm{mm}^{2}$ & 8.0 & 0 & 設計特性値 \\
\hline 引張強度 & $\mathrm{N} / \mathrm{mm}^{2}$ & 8.8 & 0 & 設計特性値 \\
\hline 破壊エネルギー & $\mathrm{Nm} / \mathrm{m}^{2}$ & 36100 & 100 & 曲げ試験による \\
\hline 弾性係数 & $\mathrm{N} / \mathrm{mm}^{2}$ & 50000 & 24000 & 設計特性值 \\
\hline 乾燥收縮 & $10^{-6}$ & $0^{* 2}$ & 800 & 材齢 28 日 \\
\hline 自己収縮 & $10^{-6}$ & 800 & 200 & \\
\hline クリープ係数 & - & 0.4 & 2.0 & \\
\hline 拡散係数 & $\mathrm{cm}^{2} /$ 年 & 0.0019 & 0.64 & 塩化物イオン \\
\hline 単位重量 & $\mathrm{kN} / \mathrm{m}^{3}$ & 25.5 & 23.5 & \\
\hline
\end{tabular}

*1 Ductal は初期養生後 $90^{\circ} \mathrm{C}$ の蒸気養生を 48 時間行う *2 $90^{\circ} \mathrm{C}$ の蒸気養生を 48 時間終了後で材齢 28 日以降

密充填理論が適用されている。そのために，マトリック 又自身のひび割れ発生強度が高く, また, 高流動, 塩害 に対する高耐久2),4) の性能を得ることができる。さらに マトリックスには直径 $0.2 \mathrm{~mm}$, 長さ $15 \mathrm{~mm}$ の鋼繊維 が容積で $2 \%$ 混入されるので, ひび割れ発生以降屯鋼繊 維が架橋効果を発揮して, 大きな引張強度とじん性性能 を有する(表-1)。

これに対して，通常のコンクリートは引張強度を設計 上，考慮できないので鉄筋により引張応力を分担させる 複合材料である。表-1に PC 橋梁で一般的に用いられ る $40 \mathrm{~N} / \mathrm{mm}^{2}$ のコンクリートと Ductal の材料特性の比 較を示す。従来の PC モノレール桁では，鉄筋による補 強が必要なためにかぶりの確保や緊張ケーブルの配置な どの制約から, 部材断面の薄肉化には限界があった（桁 長 $20 \mathrm{~m}$ の PC 桁の最薄断面厚は $190 \mathrm{~mm}$ )。Ductal は 補強鉄筋がなく, また高流動であるため構造部材の薄肉 化を可能とした（桁長 $40 \mathrm{~m}$ の最薄断面厚は $50 \mathrm{~mm}$ )。 そのために桁自重は従来の $\mathrm{PC}$ 桁に比べ約半分に低減す ることが可能となった。しかし，ここで設計上の留意事
項は，たわみの増大である。Ductal の弾性係数は従来 のコンクリートのそれ之比較して約 2.5 倍に大きい屯の の, 薄肉断面による断面二次モーメントの低下により, たわみが大きくなる傾向にある。

モノレール軌道桁は, 構造材である桁としての役割之 レールとしての役割を担っているために，一般的な析に 比較して, 桁の寸法精度が厳しい。Ductal は自己充填 する高流動材料であり，モルタルフローで $25 \pm 2 \mathrm{~cm}$ を 標準としているので，打設時にバイブレ一タを使用する ことはない。そのためにバイブレータによる型枠の精度 損失は生じないために，高精度の仕上がり寸法を保持す ることができる。また，桁高の高い薄肉断面でも材料分 離することなくコンクリート打設を確実にできる。しか し型枠に作用する側圧は, 液圧分布に近くなることを留 意することが重要である。

\section{3. 長大スパン・モノレール桁の構造概要}

\section{1 プレキャスト・セグメントの構成}

従来の PC モノレール桁は専用型枠の転用により製作 することから，プレキャスト部材となる。桁長 $20 \mathrm{~m} の$ 場合は，トレーラーによる運般が可能であるが，桁長が $40 \mathrm{~m}$ となると運搬の制約からプレキャスト・セグメン 卜に分割して製作し，現地で接合する必要がある。

本技術開発では, 図-1 の側面図に示すように, 桁軸 に対してそれぞれ 3 個の逆 U枌と 3 個の底板のプレキャ スト・セグメントから構成される軌道桁とした。3 分割 された逆 $\mathrm{U}$ 桁（逆 $\mathrm{U}$ 桁- $\mathrm{A} \sim \mathrm{C}$ ) は，相互にドライジョ イントにより接合される。また, 3 分割された底板（底 板-1〜3）相互，および桁と底板は，孔あき鋼板ジベル (PBL : Perfo Bond Leisten) を介したウェットジョイ ントにより接合される(図-2)。

本プレキャスト・セグメントの接合における特徴は, 逆U桁のドライジョイントはスパン中央よりにあり底 板相互のウェットジョイントがその外側にあり，接合位

Technical Development of a Long Span Mono-rail Girder applying Ultra High Strength Fiber Reinforced Concrete

By Y. Tanaka, T. Kobayashi, M. Ishido and M. Ohkawa

Concrete Journal, Vol.45, No.11, pp.27 34, Nov. 2007

Synopsis As ultra high strength fiber reinforced concrete (Ductal) is new generation concrete material possessing high strength, high ductility, high fluidity and high durability, it is possible to drastically reduce the dead weight of the bridges made of Ductal compared with those made of ordinary concrete. The authors have been challenging the technical development and have accomplished a $40 \mathrm{~m}$ long mono-rail girder based on the accumulated design and construction know-how for recent five years. The developed long span girder is consisted of six pre-cast segments and its cross section is a box shape. The construction and structural safety performance have been verified before the construction of a $40 \mathrm{~m}$ long mono-rail girder, through a series of experiments and FEM analyses such as a fundamental joints tests, fabrication tests using a 10 $\mathrm{m}$ long mono-rail girder and loading tests.

Keywords : ultra high strength fiber reinforced concrete, mono-rail girder, pre-cast segment, wet joint, dry joint 


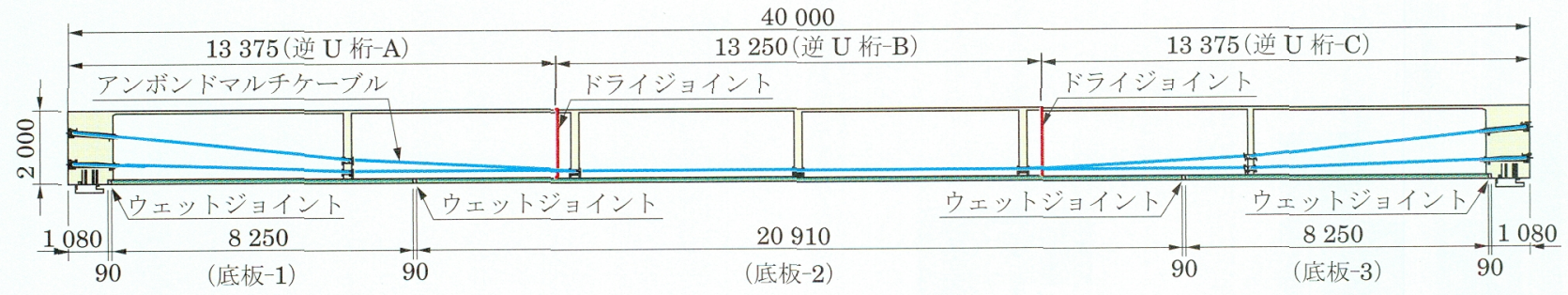

図-1 桁長 $40 \mathrm{~m}$ のモノレール桁の一般構造

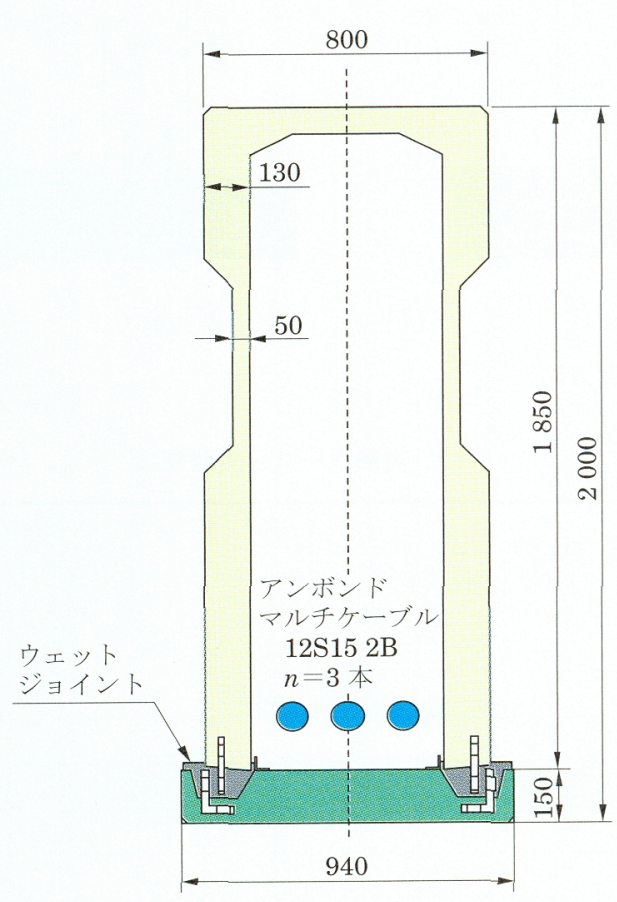

図-2 桁長 $40 \mathrm{~m}$ のモノレール桁の標準断面

置がずれていることである。モ/レール桁は単純桁であ り中央の曲げモーメントが最大となる。いずれのタイプ のジョイントも曲げ引張力に対しては抵抗できないので, 使用限界状態の設計荷重に対してはフルプレストレスと する必要がある。ところが，図-1のように桁と底板の 接合位置を異なるむのとすることにより，ジョイント位 置でフルプレストレスとする必要が無いので緊張力を低 減することが可能となった。

逆U桁と底板を分離したのは, (1)桁をボックス断面で 製作する場合には, Ductal 打設時に内型枠に多大な浮力 が働き正確な寸法精度を保持することが困難, (2)ボック ス断面のプレキャスト・セグメントは構造的には有利に なるむのの，すべて内ケーブルの PC 鋼線とする必要が あり，薄肉断面を実現できない，などの理由からである。 逆U桁の接合にドライジョイントを採用したのは, (1)軌道桁上面のゴムタイヤ走行面と側面の案内輪走行面 の接合部にギャップを発生させない，(2)現地での接合工 程期間を短縮できる，などの理由による。

このために, 二種類のドライジョイントとウェットジョ イントの技術開発の成否が，長大スパン・モノレール桁 開発のポイントとなった。

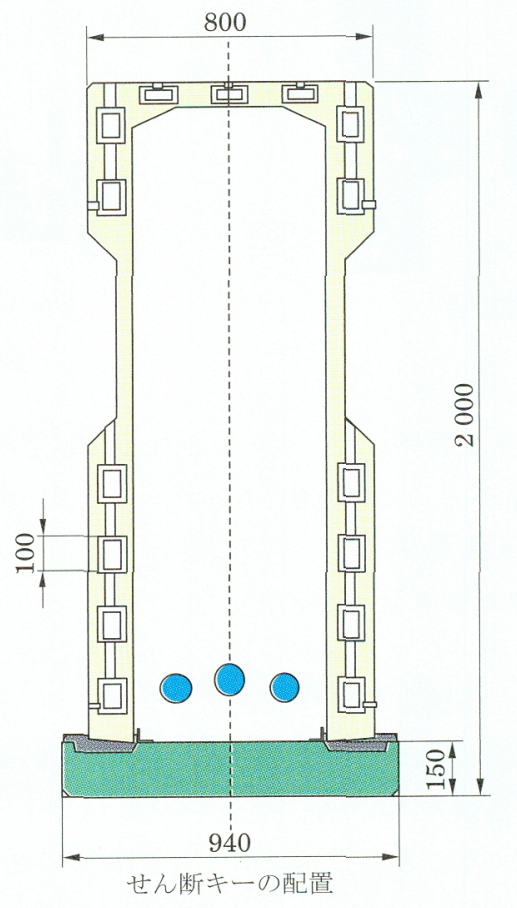

図-3 桁長 $40 \mathrm{~m}$ のドライジョイント接合端面

\section{2 ドライジョイント}

このジョイントは, 従来の PC 橋梁に適用されている プレキャスト・セグメント工法に打けるプレキャスト・ セグメントをマッチ・キャストにより製作する点では基 本的には同じ方法である。しかし，Ductal は従来のコ ンクリートに比べて，養生中の自己収縮量が大きいため に，これに対応するための技術開発が必要であった。

本ドライジョイントの接合面には，両面ともに凹形状 のせん断キーが設けられている(図-3)。従来のせん断 キーは相互に叫凸形状のキーをマッチ・キャストで製作 して接合されていた。しかし，接合面に塗布するエポキ シ樹脂の厚みなどにより，接合時に凹接合部にひび割れ が発生するリスクがあった。本ドライジョイントではド ライジョイントの仮接合後に無収縮グラウトを充てんし てせん断キーとした。

マッチ・キャストはオールド・セグメントを型枠とし てニュー・セグメントを製作することにより，接合面が 合致する形状となる。しかし, Ductal は単位セメント 量が多いために，二ュー・セグメントを製作する際にす でにオールド・セグメントの断面形状がわずかに収縮し ている。これに対処するために，マッチ・キャスト面に は断面形状のゲージとなる鋼製型枠を介して，ニュー・ 


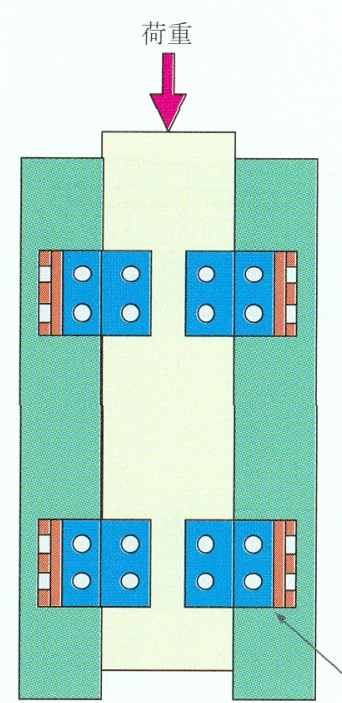

type A

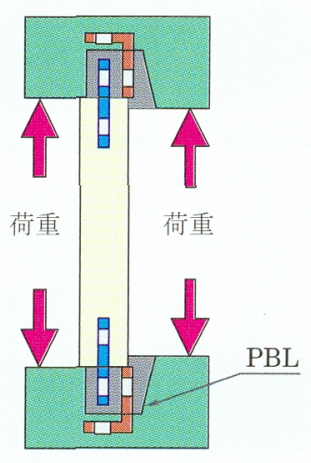

type B

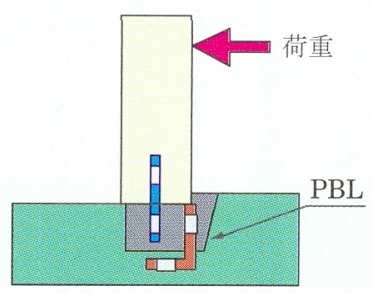

type $\mathrm{C}^{-1}$

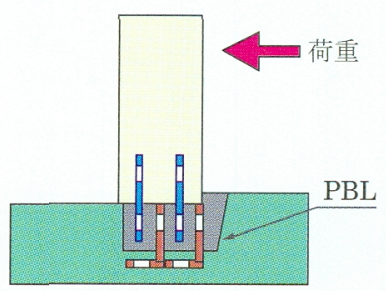

type $\mathrm{C}-2$

図-4 PBL の要素実験の載荷方法

セグメントを製作した。ゲージとなる鋼製型枠の鋼板厚 さを一定とすることにより，マッチ・キャスト面のミラー イメージを実現できた。

\section{3 ウェットジョイント}

PBL を用いたウェットジョイントは, DuctalのU 桁 ブロックと床版との接合部に適用されて,「赤倉温泉ゆ けむり橋」が完成している。このときのジョイントは 主として橋軸方向のせん断伝達を行いU桁と床版を合 成構造とすることが役割であった。今回の逆U桁と底 板のウェットジョイントは, 逆U桁と底板とのせん断 伝達のほかに桁ウェブに働く面外曲げモーメントを底板 に伝達する必要がある。また, 底板相互のウェットジョ イントは, 桁の曲げモーメント作用時に底板相互に働く 引張力を伝達しなければならない。

PBLを用いたウェットジョイントの充てん材は, Ductal を現場打設するあのである。そのために, PBL の孔に充てんされるDuctal のせん断抵抗之鋼板の面内 せん断抵抗により成立するものである。充てん材を Ductal とすることにより, 従来のように PBL の孔に鉄 筋を貫通する必要はない。

\section{4. モノレール桁の構造と機能の検証実験}

\section{1 PBL を用いたウェットジョイントの要素実験}

底板とウェブに適用するウェットジョイントには，(1) 桁軸方向のせん断抵抗, (2)引張抵抗, (3)曲げモーメント 抵抗の要求性能が求められる。せん断抵抗は枌の死荷重 時や活荷重時に発生する断面力に対する抵抗力である。 一方, 引張抵抗や曲げモーメント抵抗は, モノレールが 地震時に受ける転倒モーメントにより発生する桁軸直角 方向の断面力に刘する抵抗である。

これらの異なる方向の作用力が発生した際に, 必要と される PBL の枚数や形状, 桁ウェブの厚さの設計を行 い，系統的は確認要素実験により構造検証を行った。3 表-2＼cjkstart実験ケースと実験結果

\begin{tabular}{|c|c|c|c|c|c|c|c|}
\hline \multirow{2}{*}{$\begin{array}{l}\text { 実 験 } \\
\text { ケース }\end{array}$} & \multirow{2}{*}{$\begin{array}{l}\text { 載 荷 } \\
\text { タイプ }\end{array}$} & \multirow{2}{*}{$\begin{array}{l}\text { PBL } \\
\text { の枚数 }\end{array}$} & \multirow{2}{*}{$\begin{array}{l}\text { ウェブの } \\
\text { 幅 (mm) }\end{array}$} & \multicolumn{2}{|c|}{ 設計荷重（kN） } & \multicolumn{2}{|c|}{ 実駼結果 $(\mathrm{kN})$} \\
\hline & & & & $\begin{array}{l}\text { SLS/L } 1 \\
\text { 地 震 }\end{array}$ & $\begin{array}{l}\text { ULS/L } 2 \\
\text { 地 震 }\end{array}$ & $\begin{array}{l}\text { 縁切れ } \\
\text { 荷 重 }\end{array}$ & $\begin{array}{l}\text { 最大 } \\
\text { 荷重 }\end{array}$ \\
\hline$A-1-90$ & A & 1 & 90 & 166 & 393 & 570 & 1600 \\
\hline A-2-155 & A & 2 & 155 & 166 & 393 & 1200 & 3356 \\
\hline B-1-90 & B & 1 & 90 & 18.9 & 28.6 & 64.0 & 159.4 \\
\hline C-1-90 & $\mathrm{C}$ & 1 & 90 & 14.3 & 47.0 & 9.2 & 41.3 \\
\hline C-1-130 & C & 1 & 130 & 14.3 & 47.0 & 20.0 & 59.0 \\
\hline C-2-155 & C & 2 & 155 & 14.3 & 47.0 & 17.2 & 91.6 \\
\hline
\end{tabular}

つの異なる作用力に対して，図-4に示すようなタイプー A， B，Cの載荷方法を採用した。また，PBLはウェブ 側（孔あきフラットプレート）からと底板側（孔あきア ングルプレート) から, 各々 $n=1$ 枚ずつ突出するのを 標準としたが， $n=2$ 枚の場合も考えた。桁ウェブの厚 みは 3 種類の厚みを考慮した。これらのパラメータを組 合わせた実験ケースを表-2 に示す。試験体寸法はすべ て桁長 $40 \mathrm{~m}$ の実物大を想定したものであり, PBLの板 厚は $19 \mathrm{~mm}$ ，孔径は $30 \mathrm{~mm}$ である。

桁長 $40 \mathrm{~m}$ のモノレール桁が使用限界状態 (SLS) や L 2 地震時などの終局限界状態 (ULS) にPBL に発生 する荷重と要素実験で得られた縁切れ荷重（初期ひび割 れ発生荷重) や最大荷重との比較を表-2 に示す。PBL に発生する設計荷重は, 三次元 FEM の線形解析より求 めたもので, 設計断面力としては安全側に算定される。 また図-5には，代表的な実験ケースについて荷重と变 形の関係を示す。この結果は, タイプーA と B の断面力 の組合せに対しては, 一枚の PBL でウェブ厚が $90 \mathrm{~mm}$ で成立することを示している。しかし, タイプーCの載 荷では, PBLが一枚でもよいが, ウェブ厚が $130 \mathrm{~mm}$ 必要であることが示された。 


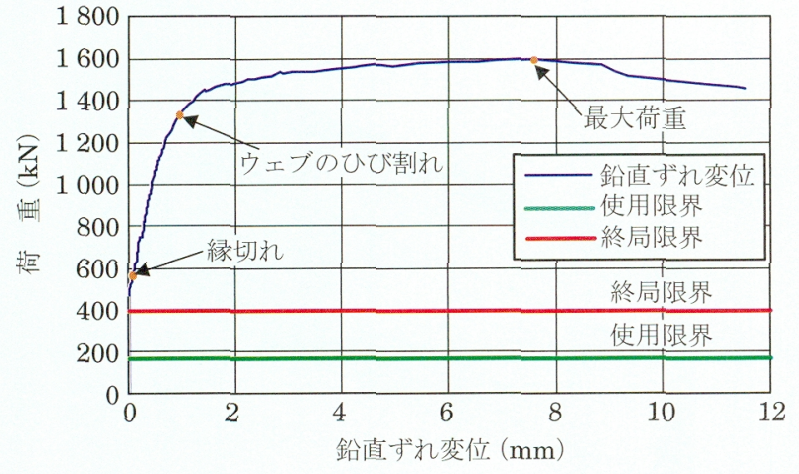

（a）試験体 A-1-90の荷重と変位の関係

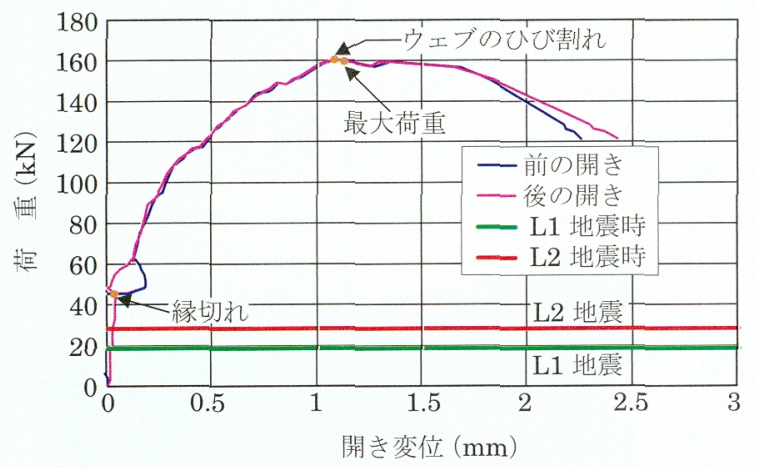

（b）試験体 B-1-90の荷重と変位の関係

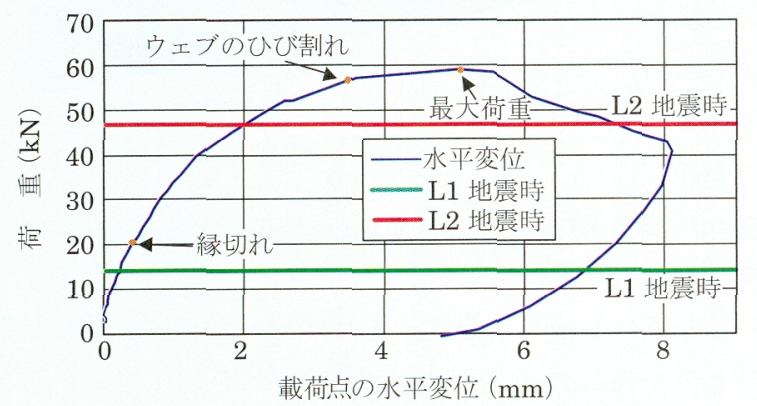

(c) 試験体 C-1-130の荷重と変位の関倸

図-5 PBL の要素実験結果

\section{2 プロトモデルによる施工と構造の検証実験}

桁長 $10 \mathrm{~m}$ のプロトモデルの構造一般とプレキャスト・ セグメントの構成，抒よびジョイントの位置を図-6に 示す。プロトモデルは，桁幅，モノレール軌道桁として の走行輪や案内輪の走行面, プレキャスト・セグメント

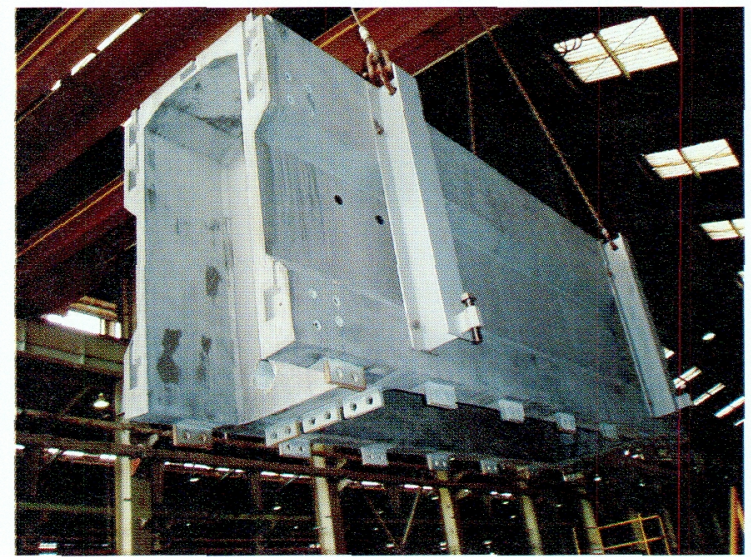

写真-2 プロトモデル逆U桁のプレキャスト・セグメント

の構成, ショィントの位置, 掞よび PBL の形状など桁 長 $40 \mathrm{~m}$ のモノレール桁と同じ寸法形状である。ただし， 桁長は $10 \mathrm{~m}$ で桁高さは $1.4 \mathrm{~m}$ 上小さい。しかし，プレ キャスト・セグメントの製作や，マッチ・キャストの施 工方法, ドライジョイントやゥェットジョイントの施工 方法などは, 桁長 $40 \mathrm{~m}$ の桁の施工方法とほぼ同じであ ると考えられる。

写真-2 に逆U桁のプレキャスト・セグメントを示す。 ドライジョイント端面のせん断キーやウェブと底板のウェッ トジョイントに用いる PBL が確認できる。底板端部に は底板相互のウェットジョイントの PBL と桁のウェブ 之接合するための PBL が設けられている。

載荷実験は図-6に示すように, ジョイント部に曲げ とせえ断力が働くように載荷位置を決めた。載荷実験の 状況を写真-3 に示す。載荷実験より得られた荷重之中 央変位の関係, おょび材料非線形を考慮した三次元 FEM 解析の結果を図-7 に示す。 $40 \mathrm{~m}$ 桁の構造検証を $10 \mathrm{~m}$ 桁で行うために, $40 \mathrm{~m}$ 梅で生ずる SLS 之 ULS で の等価な断面力を求好て, 等価載荷荷重を算定した。そ の結果, SLS では載荷荷重 $P=830 \mathrm{kN}$ となり, ULS で は $P=1748 \mathrm{kN}$ となった。載荷実験では, SLSまでの 載荷荷重を 3 回載荷してひび割机が発生しないことを確 認し, ULSの載荷荷重に対して破壊しないことを確認

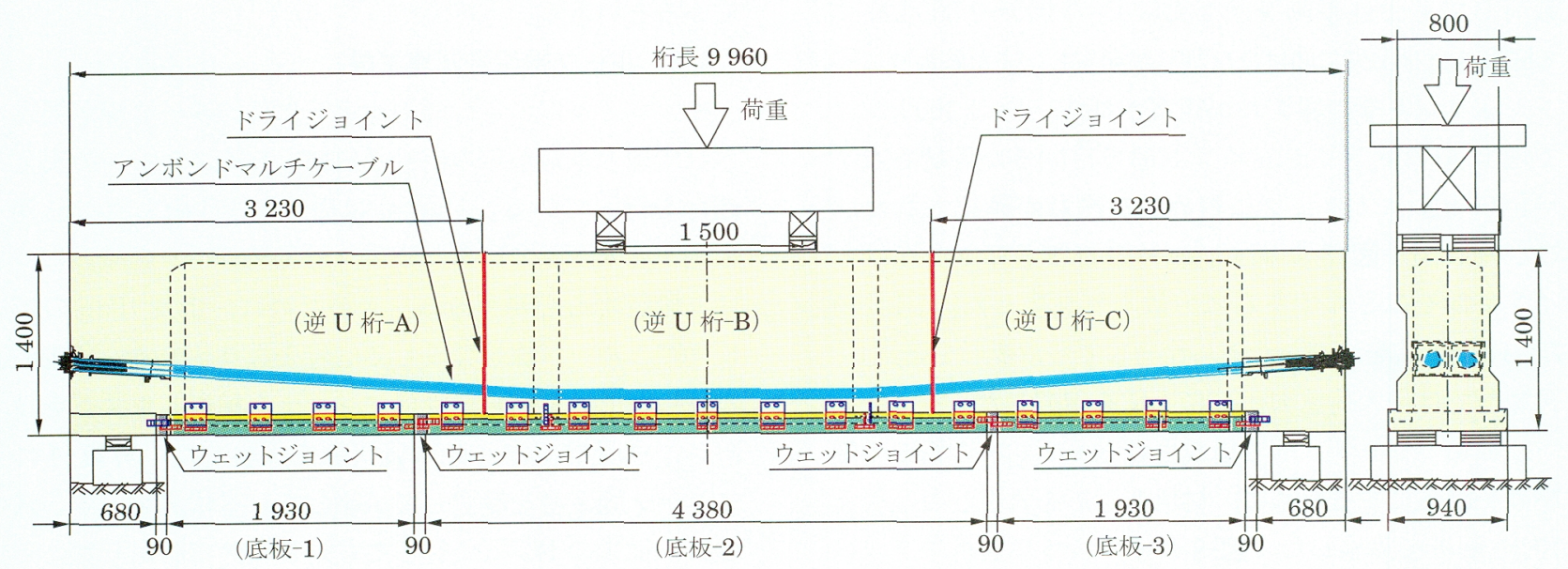

図-6 桁長 $10 \mathrm{~m}$ の一般構造之載荷方法 


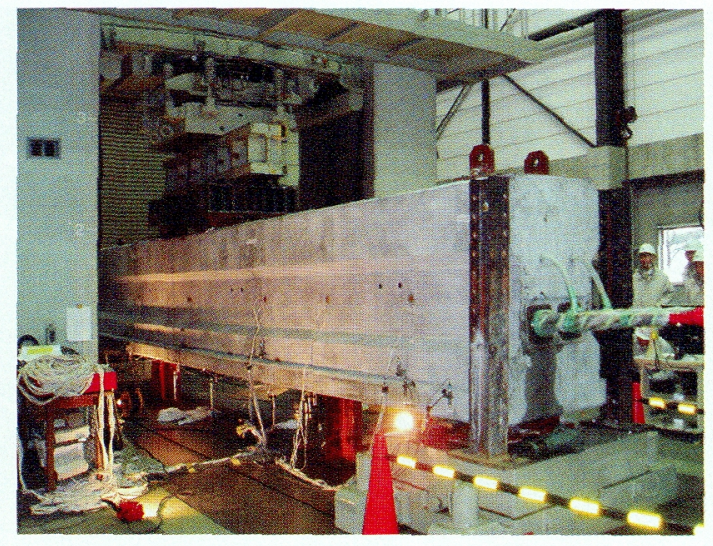

写真-3 プロトモデルの載荷実験状況

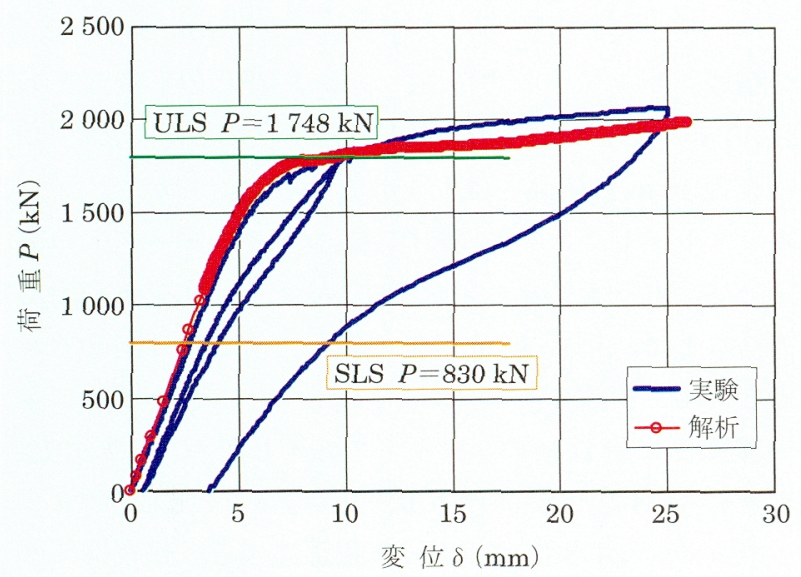

図-7 プロトモデルの実験結果と FEM 解析結果

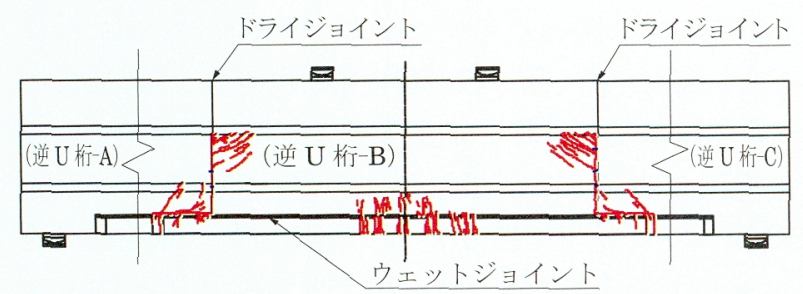

図-8 プロトモデルのひび割れ図

した。

載荷実験の結果, SLS までの載荷荷重に対して, ジョ イント部を含めてひび割れは認められず, また徐荷, 再 載荷しても弾性挙動を示した。P=1200 1300 kN に て底板スパン中央に曲げひび割机が発生し，また底板ウェッ トジョイント部の縁切れが観察された。P=1400 kNに て逆U桁のドライジョイント部で目開きが確認され $P$ $=1700 \mathrm{kN}$ にてウェブに斜めひび割れが確認された。 ひび割れ図を図-8 に示す。斜めひび割れはドライジョ イント部をはさんで左右に分散して発生した。ULS の $P=1748 \mathrm{kN}$ を到達した後, 徐荷して残留変形を確認し, 再載荷では最大荷重 $P=2067 \mathrm{kN}$ を確認した。

二種類のジョイントで構成されるモノレール桁の力学 挙動を明確にするために，材料非線形老考慮した三次元 FEM 解析を実施した。図-9に示すように解析モデルは 1/4 対称モデルとした。Ductal はりリッド要素, PBL

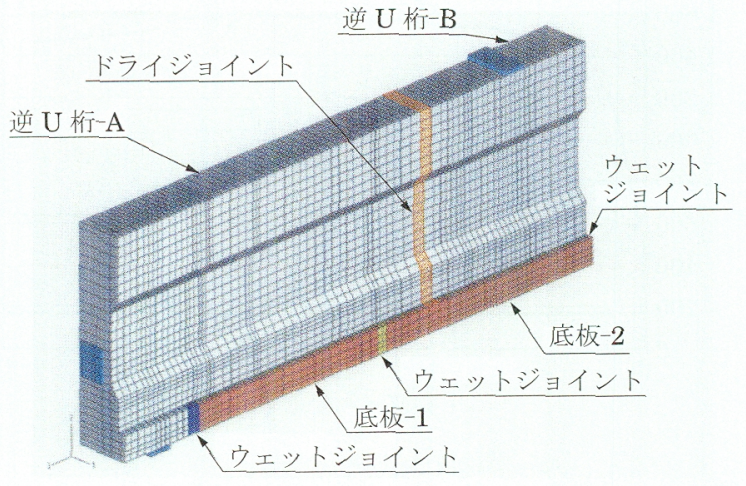

図-9 桁長 $10 m$ の 1/4 対称FEM モデル

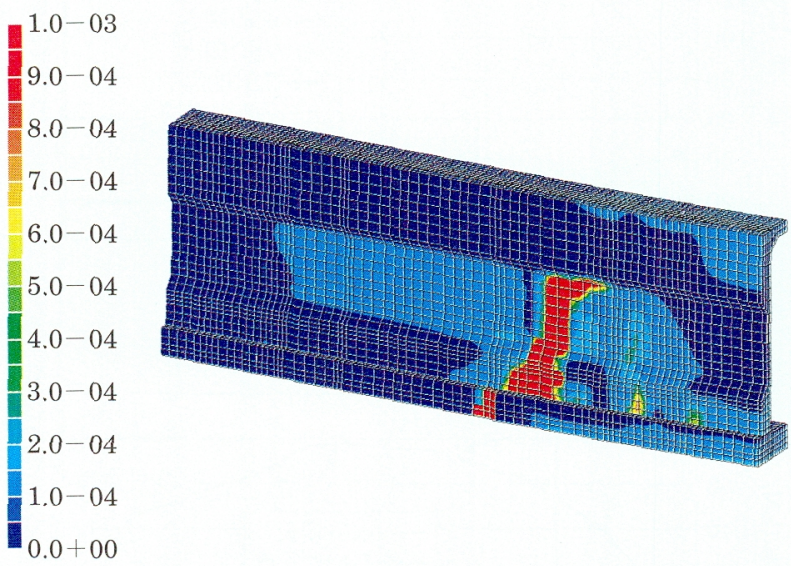

図-10 荷重 $1776 \mathrm{kN}$ ，变位 $8.0 \mathrm{~mm}$ 時の最大主ひずみ分布

のジョイントはバネ要素, また外ケーブルはトラス要素 でモデル化した。逆U桁相互のドライジョイント部と 底板相互のウェットジョイントはソリッド要素として引 張軟化特性を考虑した。PBL ジョイントのバネ特性は, 要素実験から得られた荷重之变位の関係から求めた。

ULS の載荷荷重 $P=1748 \mathrm{kN}$ 付近における最大主ひ ずみの分布の解析結果を図-10 に示す。解析結果で示さ れるジョイント近傍で引張ひずみは, 載荷実験から得ら れた観察結果とよく一致している。また, 載荷荷重と変 位の関係について屯, 解析結果は実験挙動存よく予測し ているといえる。

\section{3 ループ線信号減衰試験}

モノレール桁の走行面両サイドには，ループ線が埋設 されて地上基地からの信号受信によりモノレールの安全 運行を行っている。Ductal は従来の PC 桁と異なり鋼 繊維が混入されているために，送受信レベルの減衰につ いて確認する必要がある。そのために, 桁長 $10 \mathrm{~m}$ の桁 に実際のループ線を埋設して信号を送り，モノレールに 設计られている信号送受信アンテナを模擬した装置を設 置し，送受信レベルの減衰状態を試験した。写真-4に アンテナ固定台を設置して試験している状況を示す。試 験は，従来のPC桁に対しても同じ条件で測定した。そ の結果, Ductal 桁であ使用周波数帯域において従来之 


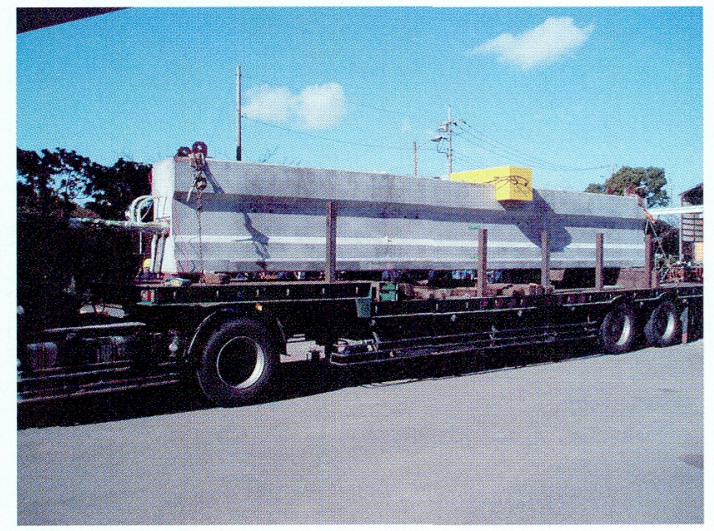

写真-4 ループ線信号減衰試験

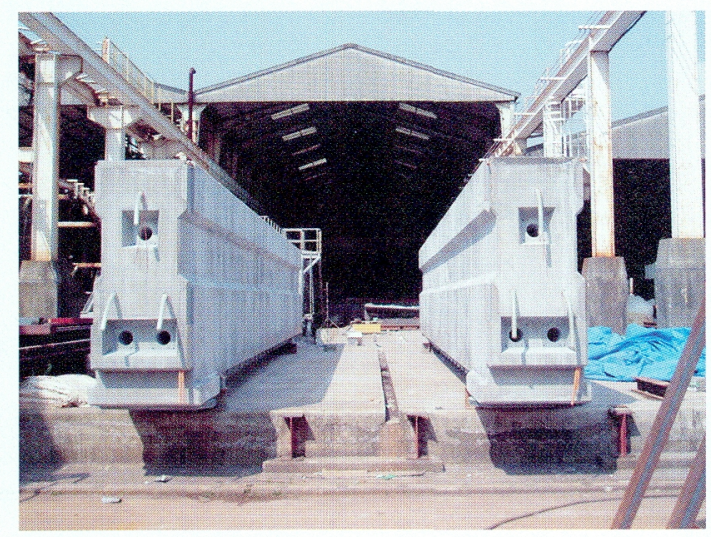

写真-5 椼長 $40 \mathrm{~m}$ の端部逆 U 桁プレキャスト・セグメント

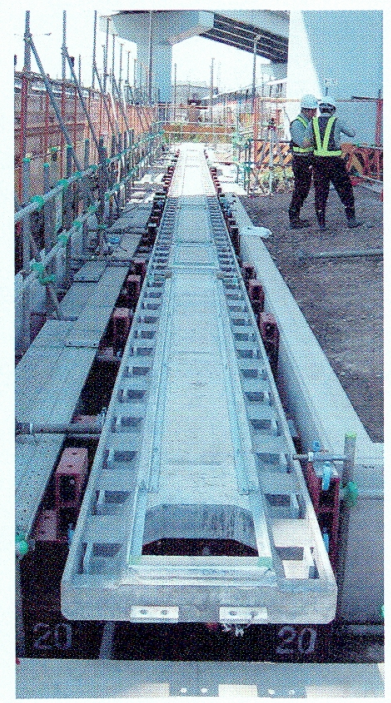

写真- 6 桁長 $40 \mathrm{~m}$ の底板プレ キャスト・セグメント

同等の減衰性能が得られ，問題ないことが示された。

5. 桁長 $40 \mathrm{~m}$ モノレール桁の施工

\section{1 プレキャスト・セグメントの製作}

プレキャスト・セグメントの構成は, 図-1に示すよう に逆 U 桁が 3 基と底板が 3 基である。逆 U 桁は自己収 縮を考慮した型枠を用いてマッチ・キャストにより製作 した。また，底板はウェットジョイントのための PBL をセットした状態で平打ち法により製作した。写真-5

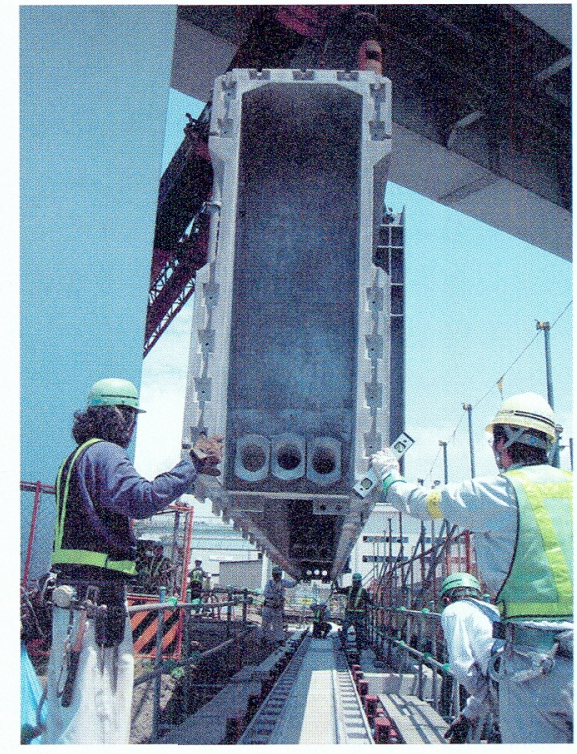

写真-7 逆U桁プレキャスト・セグメントの設置

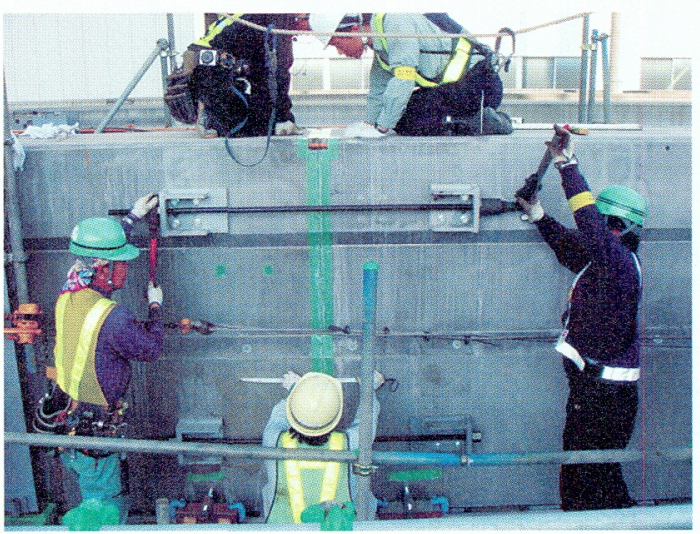

写真-8 ドライジョイントの仮接合

に両端部の逆U桁プレキャスト・セグメントを示す。

5.2 プレキャスト・セグメントの架設・接合

架設は，まずレベルをとった架設桁上の所定の位置に 3 基の底板をセットした（写真-6）。次に中央部と端部 の逆U桁プレキャスト・セグメントを，ドライジョイ ントの引き寄せの際に底板の PBL との干渉を避けるた めに，最終レベルよりあ $10 \mathrm{~cm}$ 程度上げた状態で，そ れぞれ設置した。逆U桁プレキャスト・セグメントの 設置状況を写真-7に示す。ドライジョイント端面にエ ポキシ樹脂を塗布して, 引き寄せ装置により逆U桁を 仮接合している状況を写真-8に示す。仮接合した逆 U 桁を所定のレベルにセットダウンし，底板相互とウェブ と底板のウェットジョイント部にDuctal を現場打設し た。ウェットジョイントのD Ductal を養生後, ジョイン 卜部 Ductal の圧縮強度を確認した後, 桁全長にわたり 緊張して接合を完了した。

最終の出来型は設計值通りであった。またドライジョ イント部においては, 走行面や案内輪が走行する側面の 目違いなく接合することができた。 


\section{6. おわりに}

今回のプロジェクトは, Ductal を適用したはじめての 鉄道橋の施工実績であり, 構造安全性をはじめ, モノレー ルが走行する際のレールとしての機能（例えば, 走行面 の寸法精度や摩擦係数の確保, ループ線の機能, 種々の 埋込み金物の精度など）を細部にわたる検証を経て，長 大スパン・モノレール桁として完成した。またこれまで, 従来の PC モノレール桁では桁長 $20 \mathrm{~m}$ が限界とされて いたが，これを一気に $40 \mathrm{~m}$ まで伸ばすことができた。

今後の課題としては, 長大スパンのモノレール桁を複 線桁構造として完成させることである。モノレール軌道 桁は，モノレール車両の仕様から桁幅を $80 \mathrm{~cm}$ にする 必要がある。桁長を $40 \mathrm{~m}$ にするためには桁高を現状の $1.4 \mathrm{~m}$ から $2.0 \mathrm{~m}$ にする必要があり, 単線桁単独では L 2 地震時において沓の構造や安定性に問題が生ずるため に，上下の単線を接合して複線桁として地震時の安定性 を考えることが必要である。
今回の施工実績を踏まえて, より効率的で高精度のプ レキャスト・セグメントの製作方法や，合理的な複線桁 構造之沓構造の開発を図る必要がある。なお，今回のプ ロジェクトは, 多くの関係者の協力により達成できた。 東京モノレールからは, 清水邦敏, 高木博司, 引本秀樹, 柏木一夫ら各氏の，また大成建設からは，熊谷徹，水谷 公昭, 田邊顕, 渡貴司ら各氏の協力を得た。ここに記し て，感謝の意を表します。

\section{参 考 文 献}

1）田中良弘・武者浩透・下山善秀・小林忠司：PC 橋梁に用いた超 高強度㵶維補強コンクリートの用途開発，コンクリート工学, Vol.41, No.3, pp.26〜 32, 2003.3

2）土木学会：超高強度繊維補強コンクリートの設計・施工指針（案), コンクリートライブラリー $113,2004.9$

3）田中良弘・武者浩透・大島邦裕・安部吉広：超高強度繊維補強コ ンクリートを用いた PC 橋梁の長大スパン化に関する研究開発, コンクリート工学, Vol.42, No.8, pp.30〜 36, 2004.8

4）田中良弘：コンクリートの常識を破った超高強度繊維補強コンク リートの応用, 未来材料, 第 6 巻, 第 11 号, pp.52 59, 2006. 11

$\leqslant$ 圈案内

\section{「レディーミクストコンクリートの品質保証研究委員会」報告書}

生コンへの加水問題を発端として，生コン受入れ時の単位水量検査が義務付けられるなど，これまでになくコンクリートに対 する信頼性は低下しています。関連諸技術の進歩に反して低下する生コンの信頼性を回復するために，品質保証方法をいかに行 うべきか大きな課題に直面し，製造者のみならず，その使用者むコンクリートに関連する技術者として解決を急ぐ必要がありま す。レディーミクストコンクリートはJIS 製品として売買されているにもかかわらず，その品質保証はシステム化されている とは言えず，むしろ利便性を優先するために契約すら交わさないのが実状です。

この報告書では，現状の生コンの受発注システムの課題を整理し，生コン購入者のとるべき姿勢，製造者としての品質保証の あり方, 不具合が生じた場合の補償システム, 構成材料に関する課題と期待, 生コンの性能規定, 性能発注の方法, 将来の生コ ン業界を想定したシステムなど，「レディーミクストコンクリートの品質保証研究委員会」に抢ける 2 年間の検討成果が示され ています。

1. まえがき

2. レディーミクストコンクリートに関連する規準類と用語の定義

2.1 レディーミクストコンクリートに関連する規準類 2.2 レディーミクストコンクリートに関連する用語の定義 3. レディーミクストコンクリートの品質保証の課題

3.1 レディーミクストコンクリートの品質保証の現状と課題 3.2 品質保証に関する技術的課題 3.3 レディーミクスト コンクリートの受発注システムの実態

4. レディーミクストコンクリートの品質保証方法

4.1 発注者の視点からみた品質保証 4.2 コンサルタントシステムによる品質保証 4.3 レディーミクストコンクリート の品質管理・監査システムの提案 4.4 レディーミクストコンクリートの受発注システムの提案 4.5 品質保証システムの 提案

5. レディーミクストコンクリートの性能発注

5.1 構造物に要求される性能とコンクリートの品質（性能） 5.2 施工者の視点から見た性能と仕様 5.3 性能発注に対す る製造者の対応 5.4 材料メーカーの性能発注への対応 5.5 性能発注システムの提案

6. レディーミクストコンクリートの JIS 規格のあり方

7.あとがき

付 録 レディーミクストコンクリートの性能発注の研究事例 (12 例)

A 4 判・138 ページ（2005 年刊行）／定価 3780 円（税込)，会員特価 3150 円（税込）／送料 390 円

-申込先：(社)日本コンクリート工学協会「書籍販売」係

テ102-0083 東京都千代田区趜町 1-7 相互半蔵門ビル 12 階／電話（03）3263-1573 